\title{
ホットストリップミルの計算機制御
}

美 坂 佳 助*.高橋 亮一*2

\section{Computer Control of Hot Strip Mill}

\section{Yoshisuke Misaka and Ryoichi TAKaHASHI}

\section{1.まえがき}

ホットストリップミルの計算機制御が実用段階に入つ てからすでに約 20 年が経過し，最近では，その機能は 図1に示すごとく圧延ラインのほとんどすべての範囲に 及び生産性の向上, 歩留り・原単位などの製造諸元の向 上, 品質向上, 省力などに大きな効果を上げており今や, 工場運営の頭脳として 必須の装置となつている1) 15). このような発展を支えたのはコンピュータハードウェア
の急速な進展と継続的に展開されるアプリケーションの 高度化にある。

ホットストリップの計算機制御の立場から見てつぎの 2 点がハードウェアの進展として特に重要である.1つ は演算速度の高速化であり, 表 1 に示すように, 10 年で 約 10 倍となり, 数式モデル・制御式の高級化・高精度 化を可能とした. また，他の 1 つはマイクロ・コントロ ーラーの出現であり, データフリーウェーといら通信手 段ともあいまつて，制御システムの分散化を促進し，こ

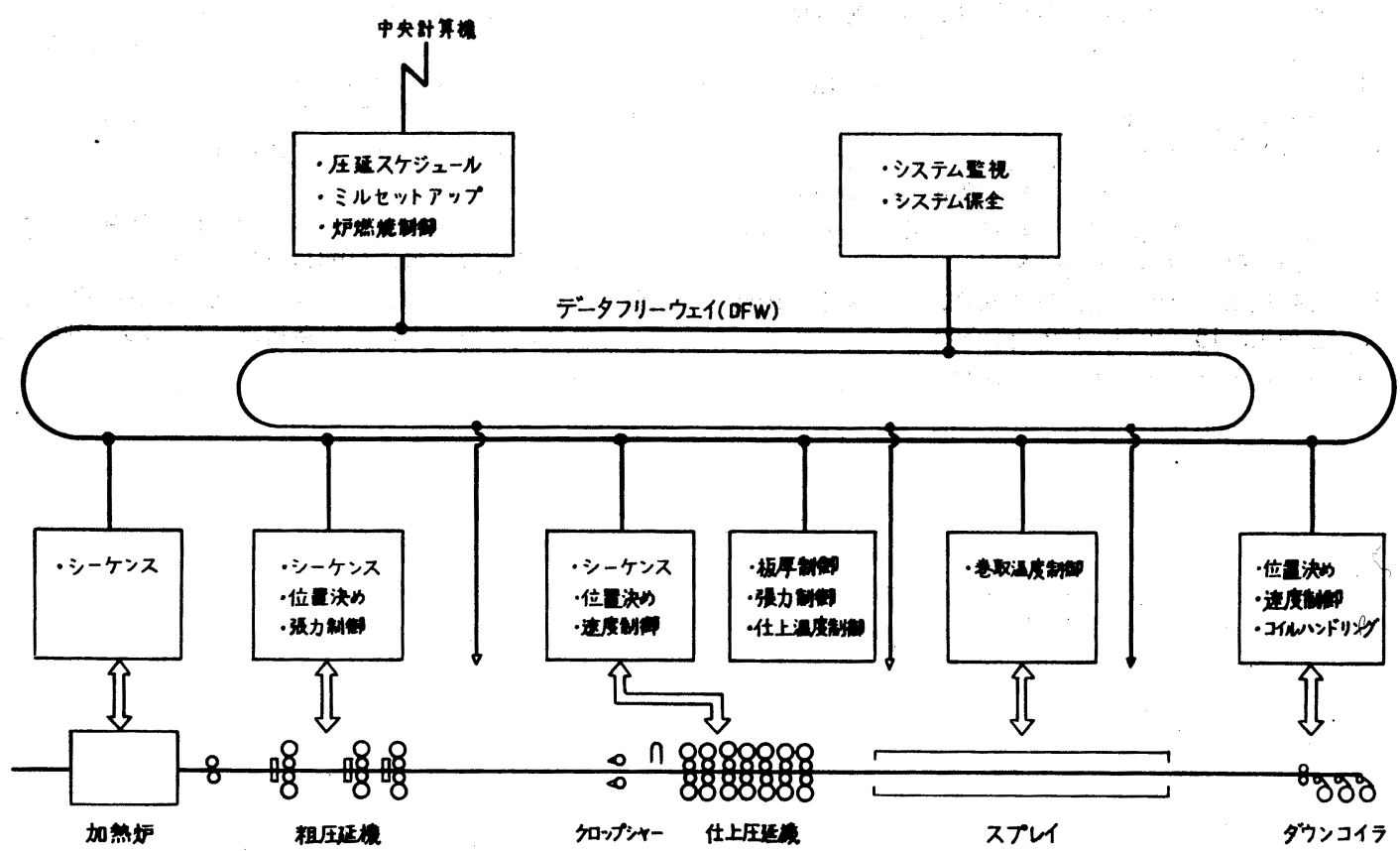

図 1 ホットストリップミル計算機制御システム19)

昭和 56 年 3 月 25 日受付 (Received Mar. 25，1981)（依頼解説)

* 住友金属工業(株)中央技術研究所 工博 (Central Research Laboratories, Sumitomo Metal Indusries, Ltd.)

*2 住友金属工業(株)中央技術研究所 (Central Research Laboratories, Sumitomo Metal Industries, Ltd., 1-3 Nishinagasuhondori Amagasaki 660) 
表 1 制御用計算機の演算速度の高速化 （住金鹿島の例）

\begin{tabular}{|c|c|c|c|}
\hline 言 & 年 & 1969 & 1981 (リプレース) \\
\hline \multicolumn{2}{|c|}{ メモリサイクル } & $2 \mu \mathrm{s}$ & $0.48 \mu \mathrm{s}$ \\
\hline 加 & 算 & $4.5 \mu \mathrm{s}$ & $0.48 \mu \mathrm{s}$ \\
\hline 掛 & 算 & $22.5 \sim 38.5 \mu \mathrm{s}$ & $1.36 \mu \mathrm{s}$ \\
\hline
\end{tabular}

れにより機能の調整・拡張・改善が比較的容易に行える よらになつた16) 20).

一方圧延そのものの研究, 特に省エネ・歩留り向上に 関する研究が進展し，これに伴つて計算機が管轄する機 能も逐年払大している.

本報では，このような背景のもとで，最近，改良・開 発が積極的になされたつぎの項目について，数式モデル を中心に述べる.

（1）加熱炉燃焼制御

（2）粗圧延機エッジャーによる幅制御

(3) 仕上げ圧延機のセットアップ

（4）仕上げ圧延機に拈ける厚み制御とスタンド間張 力制御

（5）ホットラン冷却制御

\section{2. 加熱炉然焼制御}

加熱炉燃焼制御の目的は，装入されるスラブを圧延条 件（製品寸法・仕上げ出口温度など）によつて定まる目 標温度に加熱して，圧延ピッチに合わせて王延ラインに 供給することにあるが，最小限の燃料消費量でこれを実 現することが最近は極めて強く要請される，過去にも 2,3 加熱炬制御の実施例が報告されているが，省エネ ルギの観点から近年改めて制御の方法について見直しが なされている. 特に, ホットチャージ装入がなされる場 合には冷材と同時にさまさまの装入温度の温材が炉内に 混在することになるなど操炉が極めて複雑となり，これ
に対応すべく新しい観点に立つ計算機制御システムが開 発されている. 加熱师制御システムの構成を図 2 に示し 主な機能について以下に説明する.

\section{1 スラプ温度卻年モデル}

加熱炉制御でまず必要になるのは, 当然ながら, 在妒 中のスラブの温度の把握であり, 装入温度及び実績炉温 や燃料流量から各時刻での炉内各スラブの温度を計算す る必要がある. スラブの場合は厚み方向の 1 次元伝熱モ デルで十分であるので（1）式を差分法にて解くことに より求めるのが普通である.

$$
c \rho \frac{\partial \theta}{\partial t}=\frac{\partial}{\partial x}\left(\lambda \frac{\partial \theta}{\partial x}\right)
$$

ここで, $c$ は比熱, $\rho$ は密度, $\lambda$ は熱伝導率, $t$ は時間, $\boldsymbol{x}$ は愿み方向座標, $\theta$ はスラブ温度である. スラブ表面 からの入熱計算にはガス輻射および炉壁輻射を一括した 総括熱吸収率 $\phi_{\mathrm{CG}}$ を用いるが，これは加熱炉の形状や スラブの位置あるいは輝炎温度などにより変化するため この決定は必ずしも容易ではない21)。 $\phi_{\mathrm{CG}}$ を同定するた めには，熱伝対を埋め込んだスラブを帄内に装入して昇 温過程を測温する必要があるが，最近ではこれを簡便に 行える装直も発表されている22) 23).

\section{2 抽出目栖温度の決定}

多くの場合, 治金的見地から圧延材の仕上げ出口温度 が所定範囲に収まることが必要で，このため圧延ライン 上での温度降下をドラフトスケジュール，圧延速度など を考庶して抽出時のスラブ目標温度が決定される.

\section{3 抽出ピッチの矛㴊}

前述のよらに最小限の燃料消費により加熱炉の燃焼制 御をしたいといら場合には，スラブが炉内を通過してい く速度を予測することが極めて重要である.このため, 各スラブの圧延ピッチの予測が正確に行われ，かつ，そ れに従つて央際の圧正が行われること，また，ロール替 えなどのあらかじめ定まつている休止の情報の利用はも ちろん突発休止時などす再開時刻のすみやかな入力など が望ましい.

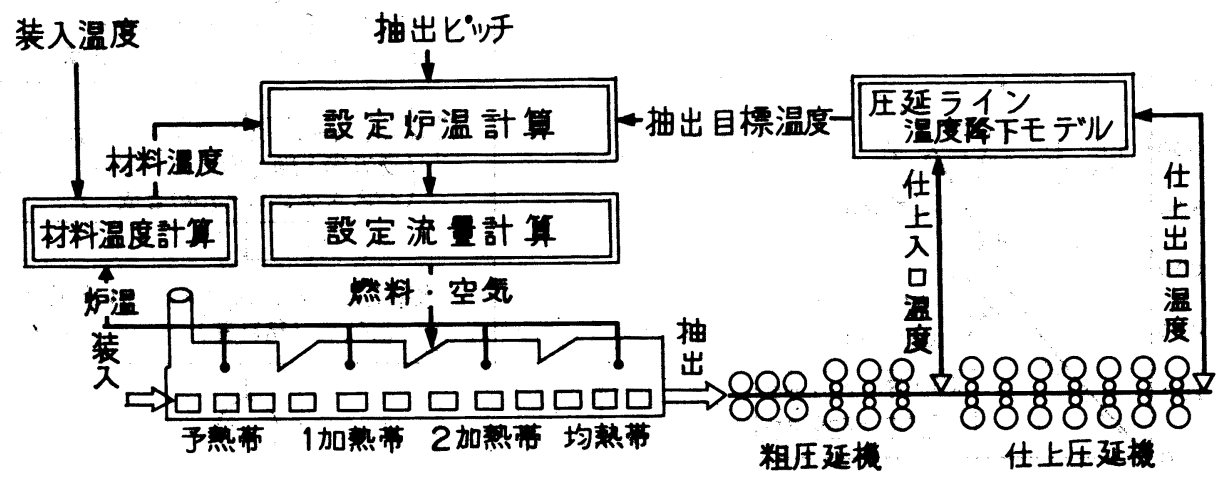

図 2 加熱 炉 制御 シ ステ ム29) 


\section{4 然烧料得}

加熱炡燃焼制御の方法として，従来から多く実施され ているのは，スラブの寸法・在炉時間・目標抽出温度ご とに「最適昇温曲線」(スラプ炉内位置とスラフの温度 の関係を示す曲線）をあらかじめ定めて扰きスラフ温度 がこの界温曲線からはずれないように炬温設定し燃料流 量をカスケード制御する方法である24) 27)。最近これと は異なる方法で実施されている例を釈介する.

日本銅管福山の方法は28)，スラブを加熱するのに必要 な投入熱量を求め, 均熱帯の流量を均熱度（スラブの表 面温度と中心温度の差で評価する）の制限により決定 し, 他のゾーンについては抽出ロに近いゾーンから順次 最大流量を配分していく方法である。

住金鹿島の方法は29)，抽出ピッチの变更などの動的な 変化に 対応できるように，昇温曲線を与えるのではな く，抽出時のスラブが所定の均熱度を持ち，かつ所定温 度に加熱できる炬温を時々刻々求めるるのである.すな わち，炬内各スラブにつて，下記の制約条件を满足 し，から炬尻側妒温を可能な限り下げて排ガスによる熱 損失を减少させるような姖温を決定する。

（1）抽出時のスラブの厚み方向平均温度が目標値以 上

（2）抽出時のスラブの表面と中心の温度差が所定値 以下

（3）各帯の炬温が実現可能なものであること

以下を現時点の炉温のもとに拈ける微小変動の問題とし て線形化し， 4 変数（各帯の炉温变更量 $\Delta T_{i}$ ) の線形 計画法の問題として解くものである. 図3は抽出ピッチ の異なるスラブに対するこのようにして求めた炬温設定 值およびスラブの昇温曲線である. 炉内には寸法・目標 抽出温度などの異なつたスラブが混在するので, 実際の 炉温設定は個々のスラブに対して求めた炉温を平均した ものとなる.

\section{3. 祖圧延譏エッジャーによる悟制御}

連続鋳造機では幅变更を頻繁には行いにくいため, 連

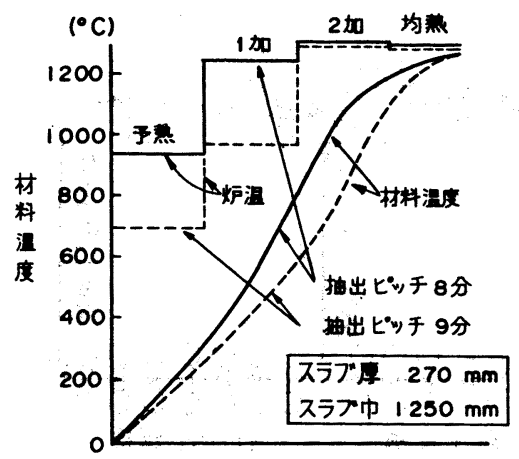

図 3 設定炉温計算の例
鋳スラブの使用量增加に伴いホットストリップミルにお。 ける幅殺し量が增大する方向にあり，かつ、エッジャー の開度設定替觉を頻繁行行ら必要性が增し，セットアッ プの重要性が增してきた。 また，加熱炉の低温抽出など の省エネルキ操妒によるスキッドマーク（スラブの楛む ら）に起因する幅変動また，先後端部のメタルフローの 非定常部に発生する幅狭をエッジャーロール開度を操作 して制御する必要性が增し自動板幅制御システムの開発 が進められている.

\section{1 エッジャーロール閶度のセットアップ}

粗圧延機において，スラブはエッジャーによる垂直压 延（幅圧下）と水平ロールによる圧延を順次受ける。 こ の時の圧延材の変形挙動について, ブラスティシンによ るモデル実験や実機ミルでの 测定が行われ，幅抎がり 量80) 322，エッジャ一の压延荷重33)などについての知見 は大幅に增大し、エッジャーロールのセットアッブ方式 は確立したといつてょい，本特集号にもとの一つが詳細 に述べられているのでは), ここでは省略する、ところで, 幅圧延時のメタルフローに起因する先後端部の幅狭の量 および長さはエッジングのドラフトスケジュールによつ て変化することは判つて拈り，後段エッジャーにて幅強

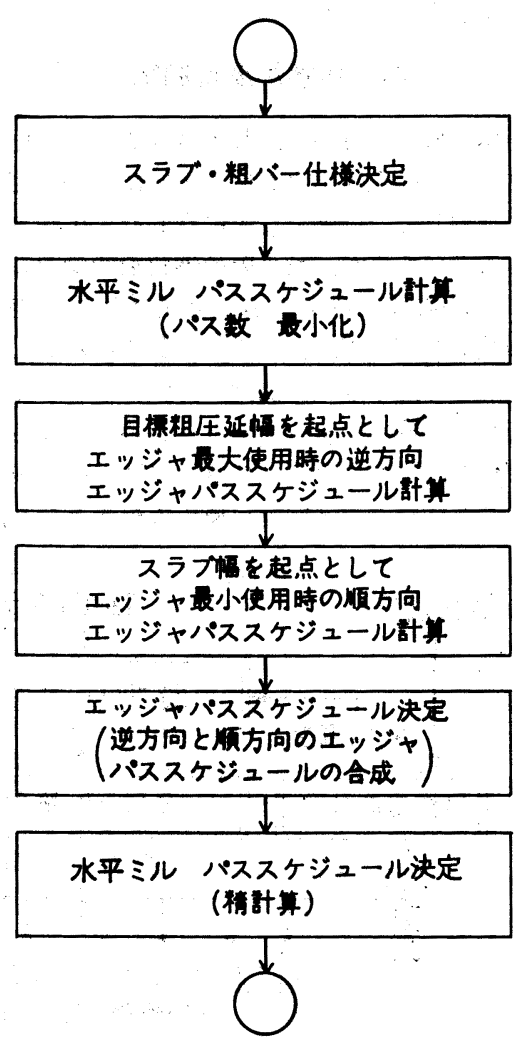

困 4 粗圧延スケジュール14) 
圧下する方が幅狭となる長さ・幅狭量ともに減少すると の実験結果にもとづき ${ }^{85)}$ ， エッシャー荷重，か及込及 角, トルク，座屈の制限の範囲で可能な限り後段エッシ ャーで幅強下寸る図4のようなスケジュール計算法を串 機に適用している例がある16.

\section{2 エッジャーロール開度による自勤板润制御}

(AWC, Automatic Width Control)

圧延材の 1 コイル内での幅変動は先後端部の幅狭とス キッドマークに起因する変動の 2 つが主要なるのであ る.

因 5 は粗圧延終了時の圧延材の先後端幅㹨および端部

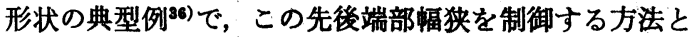
しては Davy united 社よりェッジャーロール開度を先
後端部で開放するパターン制御が提案されており 様な方法を適用したとの報告るある ${ }^{38)}$.

また，スキッドマークに対する板幅制御についてる適 用例が2，3発表されている. 新日鉄大分の例 ${ }^{38)}$ は粗圧延 機最終段のタンデム圧延機 $R_{8}, R_{4}$ のエッジャー $E_{3}, E_{4}$ にロードセルを設置し, $\mathrm{E}_{3}$ にてダージメータ式にて幅偏 差を検出し，この信号をフィードフォワードして $\mathbf{E}_{4}$ 開 度を操作するすのである．住金鹿島では ${ }^{399}$ ，図6亿示す ごとく粗圧延の中間スタンド $\mathbf{R}_{\mathbf{3}}$ の出口に幅計を設置し て幅変動を計測し，次段の $\mathrm{E}_{4}$ エッジャーを操作する方 法を採つている.

いずれにしても，エッジング任延後の水平压延による 幅变動の再生を予測して, エッジャーにより過制御しな

a) 板巾

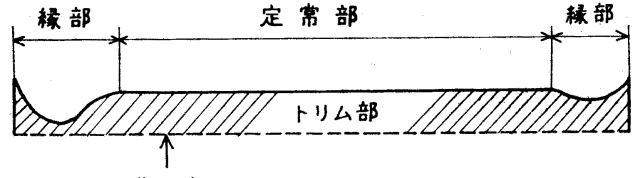

b) 端 部

成品巾

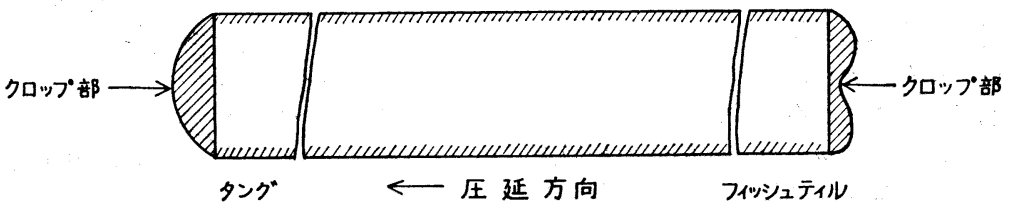

因 5 粗 圧延後の愊と端部 26$)$

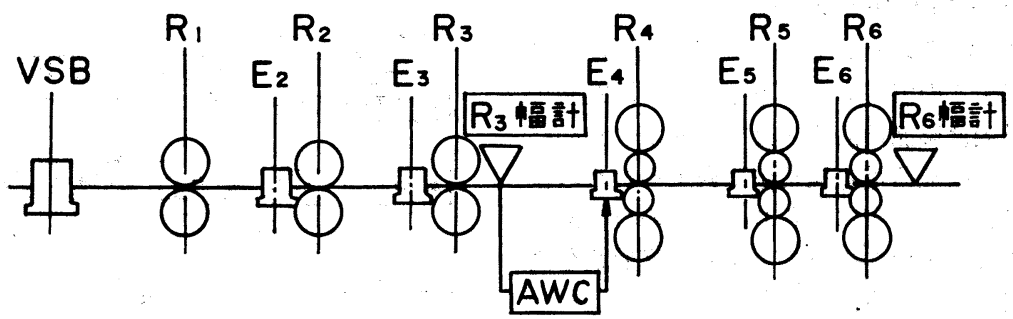

図 6 自動板愊 制御 の 例39)

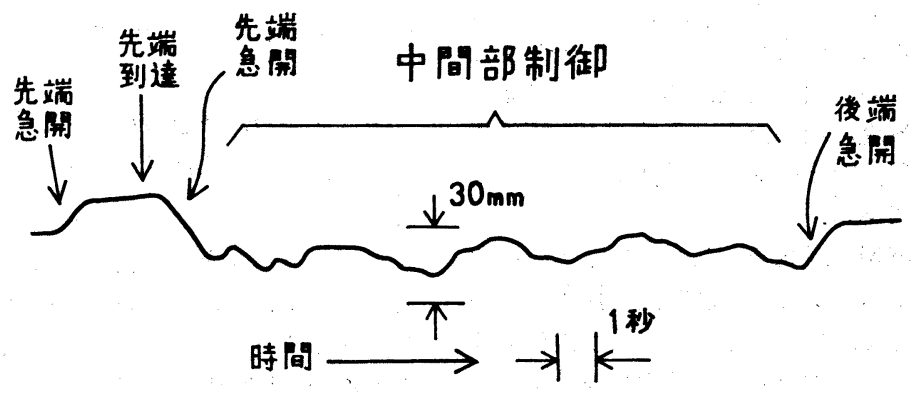

図 $7 \quad E_{4}$ 操作の例（因 8 参照） 


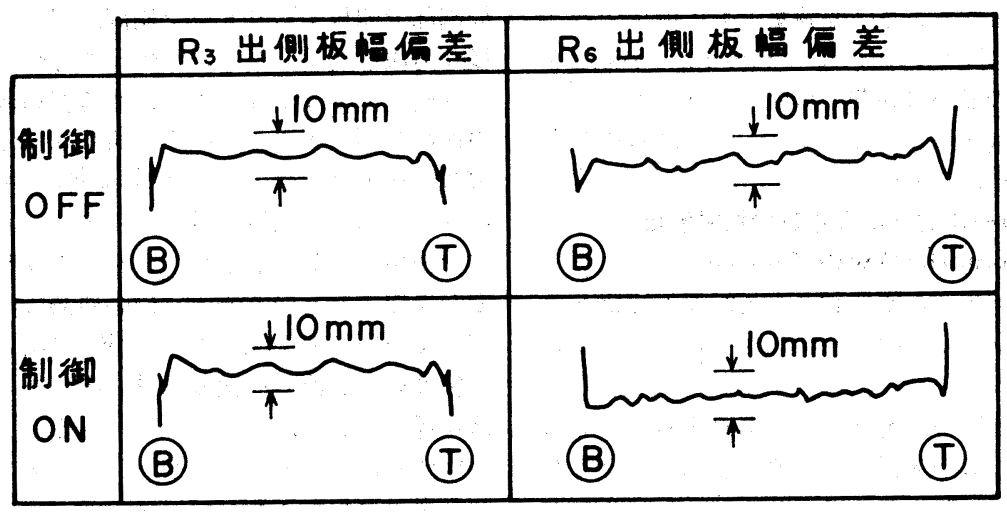

因 8 AWC 実施例39)

ければならないので幅変動の予測モデルの精度が問題と なる. 因 7 に自動板幅制御 (AWC) 適用時の $\mathrm{E}_{4}$ 開度 の操作例を，図 8 亿その効果を示すが，先後端幅狭を補 償するための動作とスキッドマークを制御するための動 作がみられ，先後端部幅狭ならびにスキッドマークによ る幅変動ともによく制御されている.

また，先後端部の幅㹟についてもプラスティシンによ るモデル実験などにより数式化が進められており 31)40), 単なるパターン制御ではなく先後端部の板幅变動に合わ せてより精度よく制御することが今後検討されると考兄 られる.このためには, エッジャーロール開度の相当急 速な操作が必要となるので油圧にて操作されることとな ろう.

\section{4. 仕上げ圧延機のセットアップ}

仕上げ圧延では， 6,7 スタンドのタンデム圧延にて最 終製品厚まで圧延するので，ロールギャップの設定およ びロール周速の設定住製品の品質・操業の安定のために 極めて重要である. 圧延荷重の推定精度向上のための検 討が精力的になされるとともに，各スタンドの負荷配分 を変更することにより鋼板のプロフィルおよび形状を制 御する手法が開発されている.

\section{1 ドラフトスケジュールの決定}

ドラフトスケジュール（各スタンドの出口厚）は動力 曲線（いわゆる HHT 曲線）を用いて，各スタンドごと の負荷配分を指定することによつて決定する方式が多く 用いられてきた11).この方式の欠点は鋼板のプロフィル および形状に対する配虑がないため，その時々の圧延機 の状況に応じて負荷配分をオペレータが修正していかな ければならないことである。

SIDMAR では GRM が開発したプロフィル・形状 を制御できるドラフトスケジュール計算法を採用してい る42). 図 9 亿示すごとく,プロフィルを表わす指標 $\Sigma$ は 中央部板厚 $H$ と板端から $40 \mathrm{~mm}$ の部分の板厚 $h_{40}$ によ り（2）式により定義し，形状を表わす指標 $\rho$ は中央部
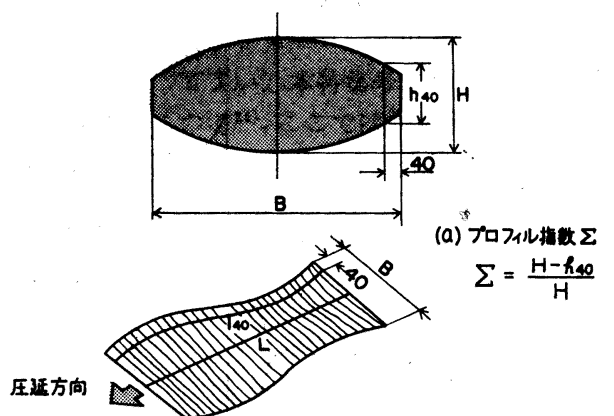

(b) 形状指数 $\rho$

$$
\rho=\frac{L-l_{40}}{L}
$$

困 9 プロフィル指数・形状指数 (2)

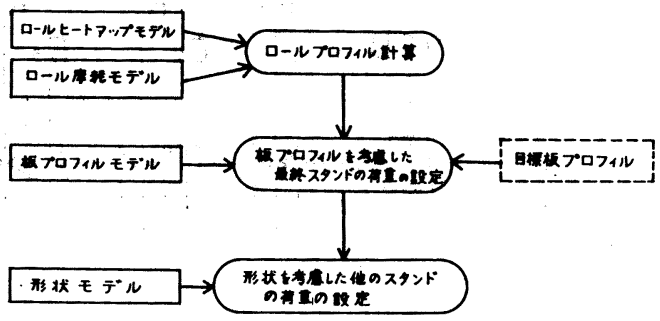

困 10 ドラフトスケジュール計算法 (2)

の伸び $L$ と板端から $40 \mathrm{~mm}$ の部分の伸び $l_{10}$ により(3) 式により定義している.

$$
\begin{aligned}
& \Sigma=\left(H-h_{40}\right) / H \\
& \rho=\left(L-l_{40}\right) / L
\end{aligned}
$$

板のプロフィルはワークロールおよびバックフップロー ルのプロフィルと圧延荷重によつて定まり，板の形状は 各スタンドに就けるロの板のプロフィル・出口の板の プロフィルおよび入口の板の形状によつて定まるもので あるから， CRM のドラフトスケジュール計算モデルは 図 10 に示すようになる.すなおち，(1口ロールのヒート 

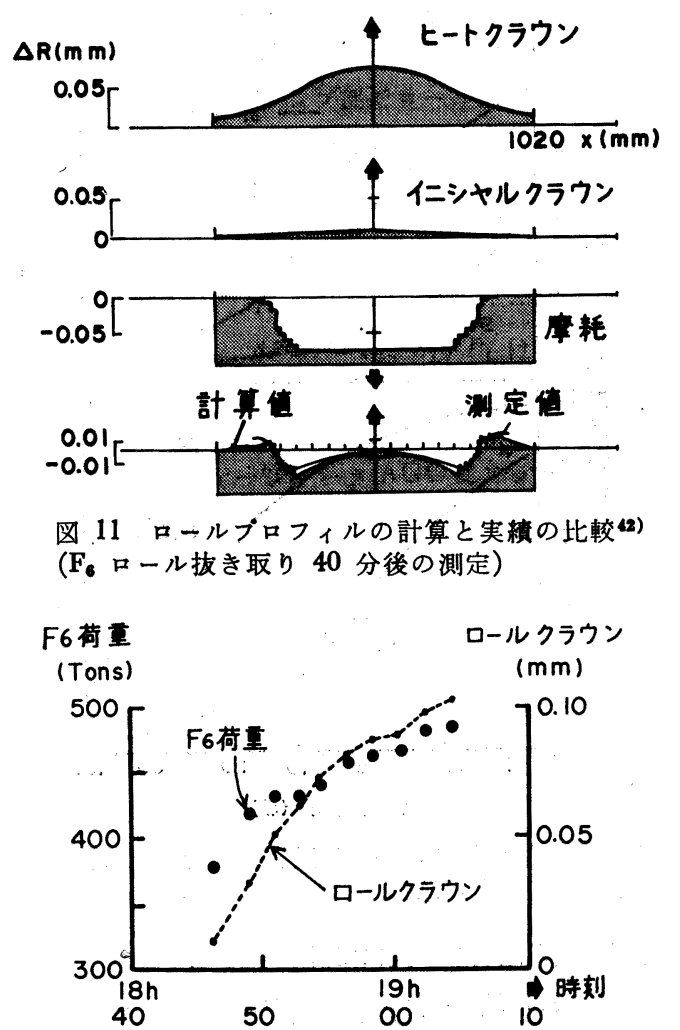

図 12 形状制御結果 4 2)（ロール替直後からの $\mathbf{F}_{6}$ 荷 重変化)

アップと摩耗のモデルよりロールのブロフィルを計算す る. (2)板プロフィル計算もデルを用いて，目標板クラウ ソが実現できるように䯅終スタンドの圧延荷重を決め る. (3)他のスタンドに対しては，形状計算モデルを用い て，平坦な銅板となるよ5に負荷を配分する。図 11 は ロールプロフィルの計算結果を示したすので実績とよく 一致している. 図 12 はこのドラフトスケジュール計算 モデルを実機に䔔用した結果で，ロール替直後からのヒ ートクラウンの変化と最終スタンドの压延荷重の变化が 示され，口ール替直後のヒートクラゥンの急激な变化 と，これを補暴するために圧延荷重がが増大しているの がよくわかる.

川鉄千葉においてる同棣に負荷配分を変更することに より，図 13 に示すよ5にロール替直後からつぎのロ ル替までの間，ほぼ一定の板クラウンに制御することが 行われている(8)。ささらに，鱼荷配分たけでなく粗厚・仕 上げ入口温度を変更して板プロフィルを制御する方法 44，あるいは，ロールの冷却水を操作することによりブ

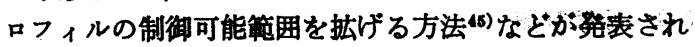
ている.

\section{2 压延荷百の推定}

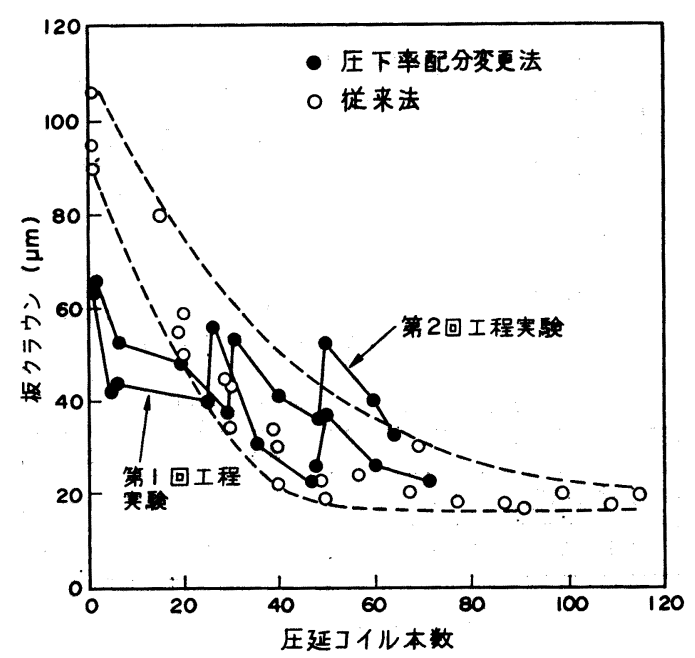

図 13 圧下率配分変更法により得られた板クラウ ンをと従来法により得られた板クラウンとの比較(3)

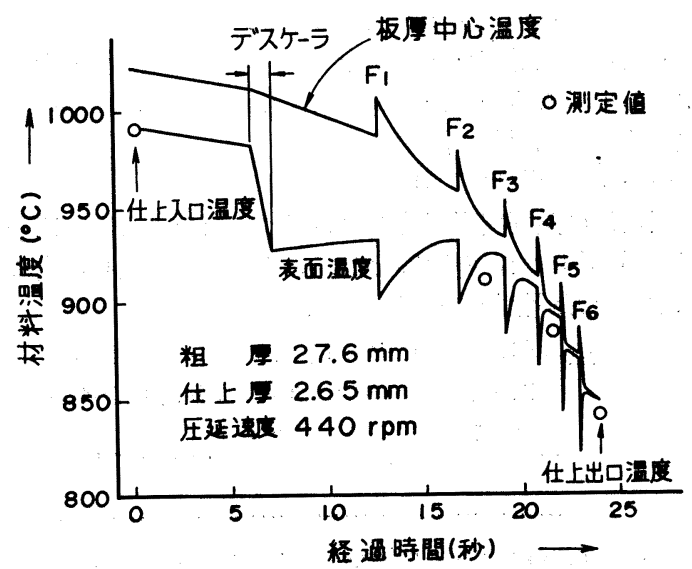

因 14 実測温度と計算温度の比較 ${ }^{47)}$

王延荷重の推定に関しては，低温域に対する変形抵抗 数式モデルや混合摩耗状態の圧延荷重計算モデルなどが 検討され，計算制御に導入されてきた.

\subsection{1 圧延温度の推定 ${ }^{46)}$}

変形抵抗を算出するため，また仕上げ出口温度を制御 するためにも材料温度を精度よく推定しなけれはなならな い. 圧延材の仕上げ圧延での温度降下については，従来 のよ5に回㛿式を用いるのではなく，板厚方向の 1 次元 熱伝導方程式（4）を表面に批る境界条件（5）のる とで解くことにより求めるよらになつてきた.

$$
\begin{aligned}
& c \rho \frac{\partial \theta}{\partial t}=\frac{\partial}{\partial x}\left(\lambda \frac{\partial \theta}{\partial x}\right)+Q \\
& -\lambda \frac{\partial \theta}{\partial x}=q \ldots \ldots \ldots \ldots \ldots \ldots \ldots \ldots \ldots
\end{aligned}
$$

ここで，Qは加工熱，qはスラブ表面からの放熱革であ 


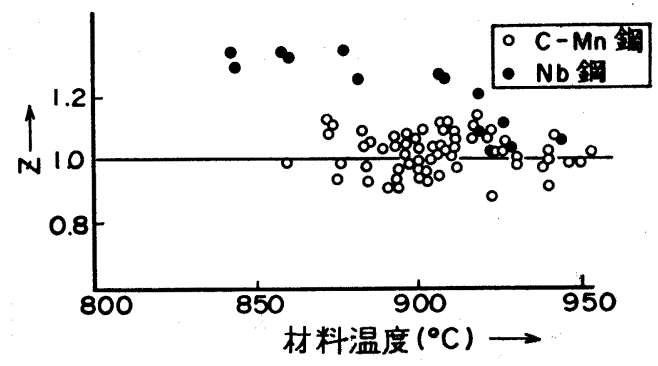

$Z=($ 実测荷重 $) /($ 計算荷重 $)$

\begin{tabular}{|c|c|c|c|}
\hline & $C$ & $M n$ & $N b$ \\
\hline$C-M n$ 鋼 & $0.03 \sim 0.61$ & $0.15 \sim 1.31$ & - \\
\hline Nb 龬 & $0.10 \sim 0.16$ & $0.70 \sim 1.01$ & $0.017 \sim 0.025$ \\
\hline
\end{tabular}

四 15 圧延荷重の推定精度 ${ }^{47}$ )

り，内訳は対流による熱損失，輻射による熱損失，デス ケーラー拉よびスタンド間スブレーによる水冷の熱損 失，ロールへの接触伝熱などである.

上記の熱伝導方程式を差分法にて解いて区延温度を算 出するのであるが，実測値ともよく一致する.（計算結 果の 1 例を図 14 に示す)

\section{$4 \cdot 2 \cdot 2$ 変形抵抗の計算}

炭素鋼の熱間変形抵抗については志田の式あるいは著 者らが Mn などの影響を加味して見直した（6）式に 示す式などが報告されている(7).

$$
\begin{gathered}
K_{\mathrm{fm}}=(0.916+0.18 \mathrm{Mn}+0.389 \mathrm{~V}+0.191 \mathrm{Mo} \\
+0.004 \mathrm{Ni}) \cdot \exp \left(0.126-1.75 \mathrm{C}+0.594 \mathrm{C}^{2}\right. \\
+\frac{2851+2968 \mathrm{G}-1120 \mathrm{G}^{2}}{T_{\mathrm{k}}} \cdot \varepsilon^{0.21} \cdot \dot{\varepsilon}^{0.13}
\end{gathered}
$$

ここで, $\mathrm{G}$ は炭素含有量, Mn, V, Mo, Ni についても

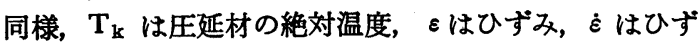
み速度である. 図 15 は実機にて（6）式の精度を調査 したものであるが G-Mn 鋼では $\pm 10 \%$ 程度の精度が 得られている. しかしながら， $\mathrm{Nb}$ 鋼の低温域での変形 抵抗が十分表現でさていない.これは $\mathrm{Nb}$ 鋼の場合は再 結晶が抑制されるため累積ひずみの影䇾が出ているた めと考えられ，この方面の研究が活発に進められてい る 48)49). 累積効果を考えた場合，(7)式による実績ひず み にによつて変形抵抗が決定されることになる.

$$
\varepsilon_{1}=\alpha_{1}+\lambda_{1-1} \varepsilon_{i-1}
$$

ここで, $\varepsilon_{1}$ は $i$ パスの実質ひずみ， $\alpha_{1}$ は $i$ パスの圧下 ひずみ， $\lambda_{1}$ は $i$ パスでのひずみ残留率である.・ひずみ 残留率は材料温度, パス間時間, ひずみ量, 材量の化学

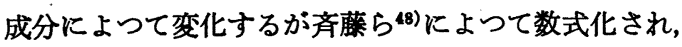
図 16 に示すごとく実験結果とすよく一致することが発 表されている.

4.2.3 圧延荷重式

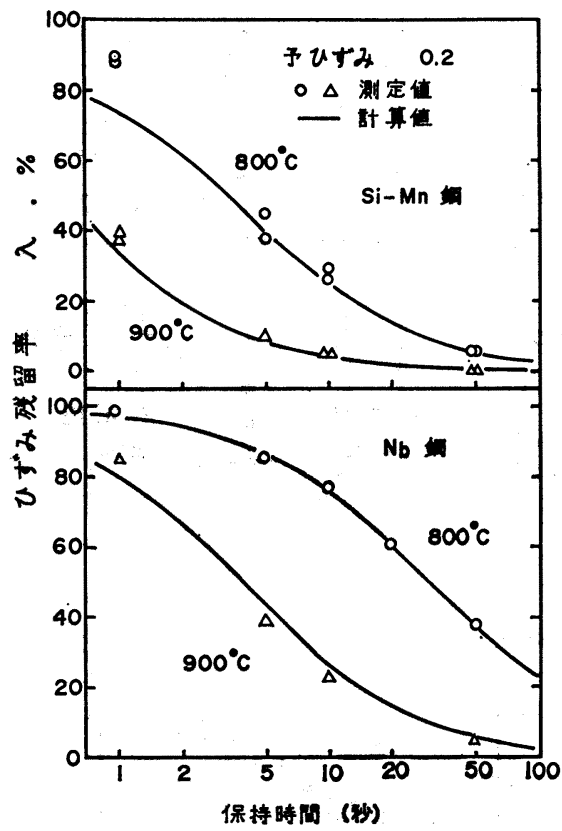

図 16 等温保持中のひずみ残留率の計算值と高温 变形実験結果との比较 ${ }^{48}$ )

\section{圧延荷重 $P$ は（8）式にて計算される.}

$$
P=1.15 K_{\mathrm{fm}} \cdot b \sqrt{R^{\prime}(H-h)} Q_{\mathrm{p}}
$$

ここで, $K_{\mathrm{fm}}$ は変形抵抗, $b$ は板幅, $R^{\prime}$ は扁平ロール半 径, $H$ はスタンド入口板厚, $h$ は出口板厚, $Q_{\mathrm{p}}$ は圧下 力関数である. 圧下力関数 $Q_{\mathrm{p}}$ としては Sims の式が使 われることが多い.

しかしながら, Sims の式は全面スティック (Stick) 状 態を前提としたるので，熱間圧延油を使用した圧延では スリップ (Slip)・スティック両領城の存在する混合摩擦 状態となり, Simsの式では十分適用できない.EL-KALAY ら50)は混合摩擦状態にす道用できるオンライン計算可能 な圧下力関数 $Q_{\mathrm{p}}$ を報告している. また混合应擦状態に おける $Q_{\mathrm{p}}$ の簡略式を作成し, 摩擦係数 $\mu=0.2 \sim 0.3$ で 実機によく合うとの報告あある

\section{5. 仕上げ圧延機の板厚猌御とスタンド間 張力制御}

仕上げ圧延機には，種々の自動制御系が設膡されてい るが,このらちでも特に重要なるのは板厚制御 (AGG : Automatic Gage Control) とスタンド間張力制御であ り，最近, より一層の精度向上のために 制御は 高度化 し, これに対応して DDG(Direct Digital Control) 化

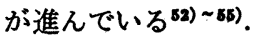

\section{1 板原都得}

ホットストリップミルの場合に通常使用される AGC の制御方式はゲージメータ AGG と Xray モニター 
AGG である. 前者は, スタンド出口板厚をゲージメー タ式により検出して制御しようとするすので，実際に は, 1 コイルの压延のトッブ部でロール開度 $S$ と圧延荷 重Pをロックオン（記憶）し，（9)式で示される圧延中 の（ロックオンした時の板厚からの）ダージメータ板厚 偏差 $\Delta h$ が零となるようにロール開度 $S$ を操作する制御 システムである.

$$
\Delta h=\Delta S+\Delta P / M
$$

ここで, $\Delta S=S-S_{\mathrm{L}}, \Delta P=P-P_{\mathrm{L}}, S_{\mathrm{L}}, P_{\mathrm{L}}$ はそれぞれ口 ックオンした時のロール開度と压延荷重である。 また，

Xray モニターAGGは $X$ 線厚み計により目標板厚から の偏差を測定し、ゲージメータ AGCにフィードバック して, ゲージメータ AGC のロックオン板厚 $h_{\mathrm{L}}\left(h_{\mathrm{L}}=S \mathrm{~L}\right.$ $\left.+P_{\mathrm{L}} / M\right)$ と目標板厚との美を補正するすのである.

AGC をDDC 化する利点の大きなるのは，圧延状態 に即したパラメータ設定ができることと高度な制御機能 が可能なことである. 以下に 2,3 の例を上げる5857).

(1)制御ゲインの圧延条件による变化への対応

ロール間腺変化 $\Delta S$ と板厚变化 $\Delta h$ の関保は (10) 式 のごとくミル㓮性係数Mと塑性係数Qによつて変わるの でゲージーータ板手偏差に対するロール間隙変更信号の 制御ゲインをそれに応じて補正する.

$$
\Delta h=M /(M+Q) \times \Delta S
$$

(2)絶対値ロックオン

セットアッブ計算結果のロール開度と压延荷重予測值で ロックオンすることにより，ゲージメータ AGC の制御 基準（ロックオン板厚 $h_{\mathrm{L}}$ ) は目標板厚にできる。

(3)フィードフォワード AGG

上流側スタンドにて外乱を検出し，下流側スタンドの口 ール間腺をあらかじ操作することにより，ロール間腺 の応答の晕れを補償する機能である. 外乱（制御しない 場合の板厚変動) の予測には, 上流スタンドの出口厚変 動に起因するすのと，スキッドマークなどにより変形抵 抗変動に起因するものの両者を考虑しなければならな い.

\section{2 スタンド同張力制侮}

通常スタンド間にはルーパーが設置されており，まず， この高さを一定に保つへくロール周速が調整される制御 システムがある. さらに, ストリップ張力を一定に保つ ためルーパートルクを調節するシステムがある．最近 は，これらの制御についてす DDG 化が進み，圧延条件 に応じた最遧ゲイン設定などきめのこまかい制御が実施 れさている15).

スタンド間にルーパーを設置せずに，図 17 のごとく 圧延電流・压延トルクなどによりスタンド間張力を演算 して,この演算張力に基ついてロール周速度を制御する ルーパーレス制御が試みられており，仕上げ压延機の前 段スタンドでの実施例が報告されている88) 〜00)。 スタン ド間張力の演算方法としては種々提案されているが，い

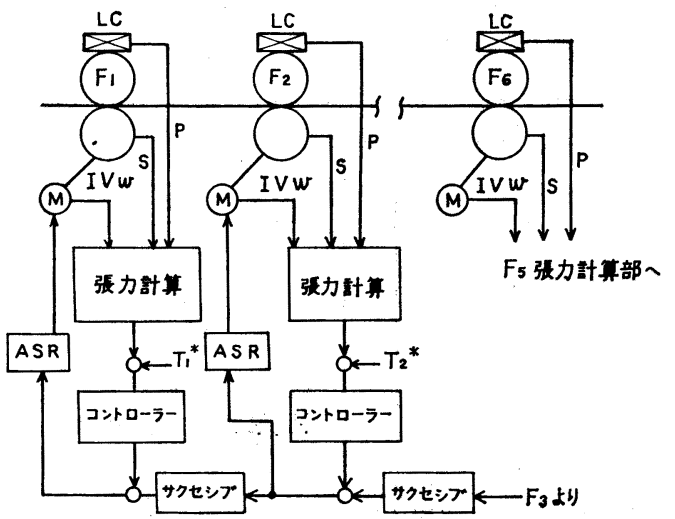

LC : ロードセル, $\mathbf{M}:$ モーター, ASR : 速度調節器, $\mathbf{P}:$ 圧延反力

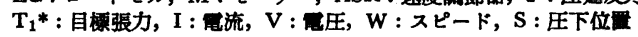
因 17 ルーパーレス張力制御システム ${ }^{88)}$

ずれも（11）式を基本としている. $G_{1}=l_{1} P_{1}-R_{\mathrm{i}} T_{\mathrm{i}}+R_{\mathrm{i}-\mathrm{1}} T_{\mathrm{i}-\mathrm{1}}$

ここで，Gは圧延トルク，Pは压延荷重，lはトルクア 一ム俰数, $R$ はロール半径, $T$ は前方張力, 添字 $i$ は $i$ スタンドを表するのである.

\section{6. ホットラン冷却制御}

ホットランテーブルでの冷却条件の鋼板の機械的性質 に及ぼす影響は大きく，最近は単に巻き取り温度を目標 値に制御するだけでなく，冷却過程る管理されるように なつてきている.

ホットラン冷却制御の機能は図 1814) に示すごとく, 仕上げ温度を測定し, 所定の巻き取り温度になるように 水冷バンクをオンオフ制御するのが一般であるが(1) 64), 冾却能力を大きくした最終バンクの直前にる温度計を設 置して最終バンクを操作する方法る実施されている65).

\section{1 野板の冷却モデル}

ホットランテーブルに护ける銅板の冾却モデルとして は, 板厚方向の温度分布を無視した (12) 式が用いられ る.

$$
\begin{aligned}
& -c \rho h \frac{d \theta}{d t}=2 \varepsilon \sigma\left\{(\theta+273)^{4}-\left(\theta_{\mathrm{a}}+273\right)^{4}\right\} \\
& +h_{\mathrm{W}}\left(\theta-\theta_{\mathrm{W}}\right)
\end{aligned}
$$

ここで, $h$ は板厚, $\varepsilon$ は輻射率, $\sigma$ はステファンボルッ マン定数, $\theta_{\mathrm{a}}$ は雾囲気温度, $h_{\mathrm{W}}$ は水冷による熱伝達係 数, $\theta_{\mathrm{w}}$ は水温である. 熱云達俰数 $h_{\mathrm{W}}$ の值については 多数の報告があるるのの (6)，銅板の温度などによつて沸 騰現象が変化するなどがかなり襍雃である. また，冷却 方式によつてす当然, 熱伝達係数は違つてくる. その他

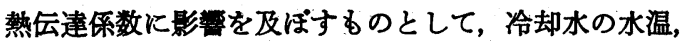
水量あるいは隣接するバンク間の冷却水の干啮などがあ るが，これらの外乱要素は極力除去することが制御精度 の向上には不可欠である. 


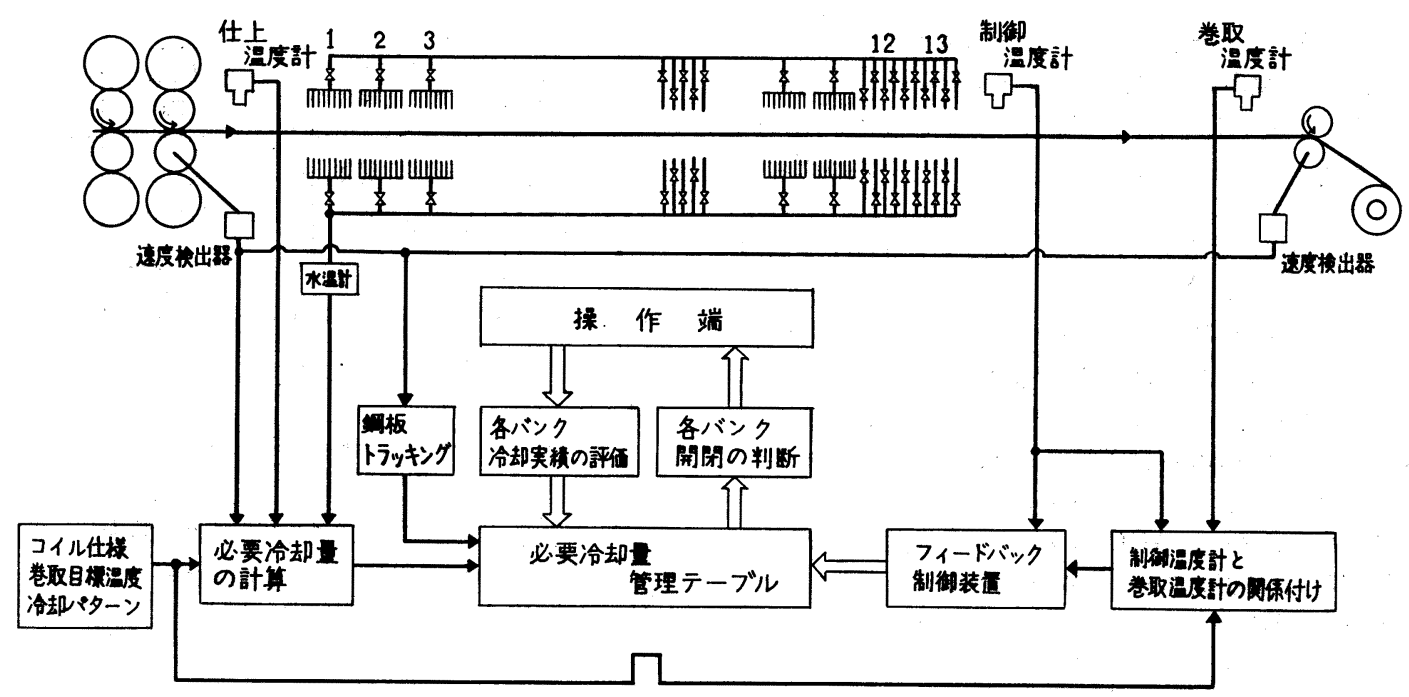

図 18 巻取温度制御システム14)

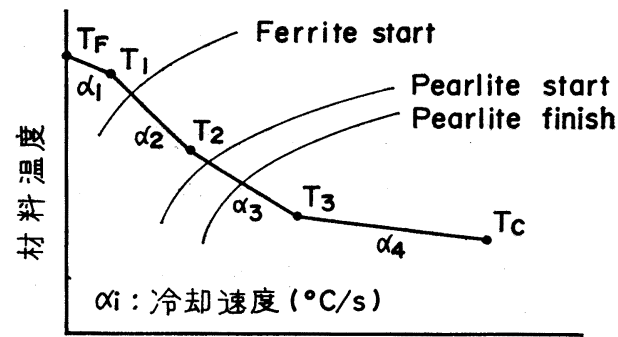

冷却時間

図 19 冷却速度制御67)

\section{2 冷却速度制整}

川鉄水島では仕上げ温度から巻き取り温度までの冾却 過程を図 19 のごとくなるよらに制御できると報告して いる(7)。これを実現するために，水冷げーンを長くし， かつ，制御単位を全長にわたつて細分化し103 個の制御 単位を設け，制御の方法としては全体を 14 個の制御ゾ ーンに分割し, 各制御ジーンの入・出口目標温度を計算 のら兄, 該当制御ゾーンの制御単位（5１0 個)を目標 出口温度にあらようにオンオフ制御する方法を採つてい る.

\section{7. と がき}

ホットストリップミルの計算機制御について，対象を 校り，数式モデルの考方方を中心に述へてきた。この他 にも重要なるのとして, 生産管理用計算機との結合によ るスラブヤードおよびコイルヤードの制御14)88) 71)，加 熱炉まわり，粗圧延機・仕上げ圧延機・コイラーまわり の自動化など多数あるが紙面の都合上割愛した。

笅しい経済環境下，計算機制御に対する要求はますま
す䈗しく，完全自動化，よりいつそうの歩留り・品質の 向上のためにまだまだ解決しなければならない問題も多 く，今後とも研究開発が精力的に進められるであろう.

\section{交献}

1）野坂康雄：鉄鋼業のコンピュータ・コントロール, (1970), p. 193 [産業図書]

2) 岡本豊彦: 鉄と鋼, 57 (1971) 10, p. 127

3 ) G. F. HeCK, $A . B$. Brown, and J. C. Mcradden: Iron Steel Eng. (1972) Apr. p. 44

4) C. G. Eades and $J$. G. Livesey: Iron Steel (1972) Oct., p. 490

5) J. Barinage and $L$. $W$. Spadlin: Iron Steel Eng. (1972) Dec., P. 52

6) K. S. Kratz: Iron Steel Eng. (1974) Sept., p. 41

7) C. $W$. Gullen and G. P. Petrus: Iron Steel Eng. (1979) Nov., p. 25

8 ) 黒津亮二, 豊坂秀夫, 伊藤 実, 片岡健二, 峰松 隆呞, 御国 尚：川崎製鉄技報, 3 (1971) 3, p. 35

9) T. Oxamoto and $K$. Nishizawa: The Sumitomo Search (1971) 6, p. 21

10）有村 透，岡戸 充，鎌田正誠：日本鋼管技報 (1972) 56, p. 31

11）宮崎義利, 伊藤 裕, 村上 豊, 前原慎一郎, 神 崎昌久: 製鉄研究 (1973) 279 , p. 42

12）滝沢謙三郎，今村 弘：神戸製鋼技報， 24 (1973) 4, p. 22

13）大庭半次, 牧角一弘, 白杉 茂, 宮野泰孝: 東芝 レビ $=-, 30$ (1975) 10, p. 768

14）藤井靖治, 笹生宏明, 大高晋一郎, 野間吉之介, 真壁英一，岩本宗孝：日本鋼管技報（1980） 85, p. 19 
15）田中英輔，芦沢誠一，中田隆正：神戸製鋼技報, 30 (1980) 4, p. 38

16) 久保岳明, 小坂晃義：日立評論，58(1976) 6, p. 17

17) 白杉茂ほか：東芝レビュー，31（1976）11， p. 935

18）辻 順一, 川崎宗男, 捠崎芳治, 小寺嘉一, 渡辺 文夫：三菱電機技報，51（1977）8，p. 519

19) 富樫伸行, 白井敏雄, 諸岡泰雄, 增田崇雄: 日立 評論, 60 (1978) 7, p. 11

20）川崎宗男, 三浦敬一, 稲本 惇, 小寺嘉一, 山本 修: 三菱電機技報，53 (1973) 3，p. 207

21）連続鋼片加熱炉における伝熱実験と計算方法，日 本鉄鋼協会編 (1971)

22) $H$. $H$. Emschermann, $B$. Fuhrmann, and $D$. Huhnke: Stahl u. Eisen, 96 (1976) 25/26, p. 1290

23）阪本喜保, 田村洋一, 横井玉雄, 川野晴雄：鉄と 鋼, 65 (1979), S 273

24) F. Hollander and $R$. L. Huisman: Iron Steel Eng. (1972) Sept., p. 43

25) $R . D$. Glatt and $F . X$. Macedo: Iron and Steel Intern. (1977) Dec., p. 381

26) C. E. Peck: Iron Steel Eng. (1973) Oct., p. 50

27) J. C. Price: Iron Steel Eng. (1980) Sept., p. 59

28) $K$. Y AbUUchi, $K$. Shiraishi, $K$. Kusumoto, $M$. Kamata, $A$. TAkekoshi, and $H$. Murakami: Proc. of International Conference on Steel Rolling, Sept.-Oct. 1980 Vol. 1, p. 151

29）高橋亮一，川野晴雄，横井玉雄，成合靖正，高力 満：鉄と鋼, 64 (1978), S 252

30）山口道広, 美坂佳助, 河野輝雄, 芝原 隆, 布川 剛, 平松照生：第 29 回塑性加工連合講演会講演 論文集 (1978), p. 142

31) 岡戸 克, 有泉 孝: 昭和 54 年度塑性加工春季 講演会講演諭交集 (1979)，p. 497

32）長田修次, 荒木省一, 中島浩衛, 神山藤雅, 吉田 一：昭和 54 年度塑性加工春季講演会講演論交集 (1979)， p. 489

33）岡戸 克, 中内一郎, 有泉 孝, 日高幸男, 金原 理：昭和 52 年度塑性加工春季搼演会講演論交集 (1977), p. 121

34）芝原 隆, 美坂佳助, 河野輝雄, 高力 満, 竹本 裕：鉄と鋼, 67 (1981), p. 15

35) 武井弘光, 䔩内捷文, 山崎喜政, 岡戸 克, 有泉 孝: 昭和 54 年度塑性加工春季講演会講演論文集 (1979), p. 501

36) $H$. Wladika, $E$. Neuschütz, and $H$. Thies:

Stahl u. Eisen, 100 (1980) 12, p. 631

37）特許公報出願公告, 昭 47-47223 (1972)

38）瀬涛康徳，武田曂吉：昭和 52 年度塑性加工春季 講演会講演論文集 (1977)，p. 117
39）新城昭夫, 布川 剛, 高力 満, 竹本 裕, 河野 輝雄, 高橋亮一: 鉄と鋼, 66 (1980), S 966

40) 荒木省一, 長田修次, 中島浩衛, 神山藤雅, 吉田 一：昭和 54 年度塑性加工春季講演会講演論交集 (1979), p. 493

41）今井一郎：日本機械学会誌, 74 (1963) 534, p. 938

42) $S$. Wilmotte, $M$. Economoroulos, $R$. Colin, and G. Thомas: Iron Steel Eng. (1977) Sept., p. 70

43）鑓田征雄, 北村邦雄, 中川吉左衛門, 玉井敏行, 君嶋英彦：塑性と加工， 21 (1980) 238, p. 990

44）土屋健治, 福田武幸, 若子敦弘, 猪井善生：鉄と 鋼, 61 (1975), S 552

45) J. Mignon, $J$. Vinciotti, and S. Wilmotte: Proc. of International Conference on Steel Rolling, Sept.-Oct. 1980, Vol. 1, p. 399

46) 浜渦修一，菊間敏夫，中島浩衛，細見紀幸：昭和 55 年度塑性加工春季講演会講演論文集 (1980), p. 53

47）美坂佳助, 横井玉雄, 高橋亮一, 永井 博: 鉄と 鋼, 67 (1981), A53

48）斎藤良行, 榎並禎一, 田中智夫, 井上正敏：鉄と 鋼, 67 (1981)，A45

49）山本定弘, 藤田米章, 大北智良, 大内千秋, 大須 賀立美：鉄と鋼，67 (1981)，A49

50) $A . K . E . H . A$. El-KalAY, and $L . G . T$. Sparling: JISI (1968) Feb., p. 152

51）寺門良二, 中島明一, 高橋 譫：鉄と鋼, 65 (1979)，S 790

52) 三浦 恒, 今道周雄, 稲本 惇: 計測と制御, 11 (1972) 5 , p. 41

53）金倉三養基，大石明良，小薮俊昭，谷口政隆，柿 田和俊, 中島興範, 浜猗芳治, 渡辺交夫:

鉄と鋼, 66 (1980)，S 299

54）小寺嘉一，渡辺交夫：第 22 回自動制御連合講演 会 $(1979)$, p. 305

55）今井一郎, 藤田紀久, 大石明良, 安田和數, 赤時 恵，中島興範，小寺嘉一，戸叶秀晴：鉄と鋼，66 (1989), S 300

56) 平山行夫, 浅田宏一, 山崎雅邦, 石川秀一, 高路 勝彦：日新製銅技報 (1979) 41, p. 43

57）高橋亮一, 美坂佳助：塑性と加工，16（1975） 168 , p. 25

58) 今井一郎, 大石明良, 谷口政隆, 中島興範, 田代 和幸，小西政治，諸岡泰男，谷藤省也：鉄と鋼， 66 (1980), S 301

59) $J$. Axamatsu, $R$. Terakado, $Y$. Anbe, $K$. Sekigughi, $M$. Miyokawa, and T. Miyamoto: Proc. of International Conference on Steel Rolling, Sept.-Oct. 1980 Vol. 1, p. 410

60) $A$. Oishi, $M$. Kasai, $O$. Nakashima, $S$. Konishi, $M$. Kawasaki, $Y$. Hamasaki, and $F$. Watanabe: Proc. of International Conference on Steel Rolling, Sept.-Oct. 
1 (1980) p. 418

61) F. Hollander: Iron Steel Eng. (1971) Mar., p. 81

62) H. F. Izzo: Iron Steel Eng. (1972) June., p. 57

63) E. N. Hinriahsen: Iron Steel Eng. (1976) Oct., p. 29

64）小野正久, 黒川知明, 平尾交樹, 武田 英：鉄と 銅, 62 (1976), A57

65) S. Wilmotte, F. Degee, C. V. D. Hove, and $M$. Economopoulos: Proc. of International Conference on Rolling, Sept.-Oct. 1980 Vol. 1, p. 1342

66）日本鉄鋼協会編：鋼材の強制冷却(1978)，p. 206
67）三宅裕史, 西出輝幸, 守谷正一, 池永孝雄, 井上 利夫，高木 清：川䗁彆鉄技報，10（1978）1， p. 58

68) $A$. JAEschke, $F$. Schröder, and $G$. SaHwIDEsKI: International Meeting on Iron and Steel Making, (1976), 5.3.9

69) 近藤 徹, 池田 博, 城田 涉, 名村明教, 江口 康二郎，三宅裕史：川崎製鉄技報，10（1978）4, p. 59

70) 中川 勝, 谷本善男, 騎馬 勝, 高力 満: 住友 金属: 30 (1978) 4, p. 113

71）津久井孝史, 岡部久郎, 秋浜雄一, 庄司秋夫, 関 幸一, 今井 隆, 石田 康, 明石吉三:

日立評論, $63(1981) 2$, p. 51 